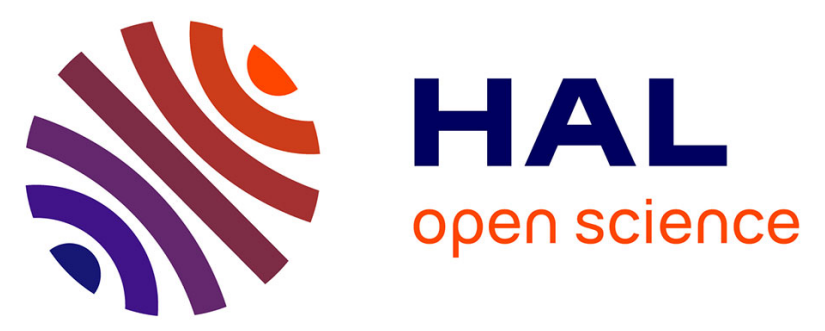

\title{
Novel one-step synthesis and characterization of bone-like carbonated apatite from calcium carbonate, calcium hydroxide and orthophosphoric acid as economical starting materials
}

Doan Pham Minh, Ngoc Dung Tran, Ange Nzihou, Patrick Sharrock

\section{To cite this version:}

Doan Pham Minh, Ngoc Dung Tran, Ange Nzihou, Patrick Sharrock. Novel one-step synthesis and characterization of bone-like carbonated apatite from calcium carbonate, calcium hydroxide and orthophosphoric acid as economical starting materials. Materials Research Bulletin, 2014, 51, p. 236-243. 10.1016/j.materresbull.2013.12.020 . hal-01611993

\author{
HAL Id: hal-01611993 \\ https://hal.science/hal-01611993
}

Submitted on 20 Oct 2018

HAL is a multi-disciplinary open access archive for the deposit and dissemination of scientific research documents, whether they are published or not. The documents may come from teaching and research institutions in France or abroad, or from public or private research centers.
L'archive ouverte pluridisciplinaire HAL, est destinée au dépôt et à la diffusion de documents scientifiques de niveau recherche, publiés ou non, émanant des établissements d'enseignement et de recherche français ou étrangers, des laboratoires publics ou privés. 


\title{
Novel one-step synthesis and characterization of bone-like carbonated apatite from calcium carbonate, calcium hydroxide and orthophosphoric acid as economical starting materials
}

\author{
Doan Pham Minh *, Ngoc Dung Tran, Ange Nzihou, Patrick Sharrock \\ Université de Toulouse, Mines Albi, UMR CNRS 5302, Centre RAPSODEE, Campus Jarlard, F-81013 Albi cedex 09, France
}

\begin{abstract}
A B S T R A C T
There is growing interest in the development of substituted calcium hydroxyapatite (Ca-HA) for biomedical applications. Carbonated apatite (CAP) appears as an important substituted Ca-HA because of its better biocompatibility compared to pure $\mathrm{Ca}-\mathrm{HA}$. This paper reports a novel pressure-mediated onestep synthesis of CAP starting from orthophosphoric acid, calcite and calcium hydroxide as available and high-purity starting materials. Under moderate synthesis conditions $\left(80^{\circ} \mathrm{C}\right.$ and $<13 \mathrm{bar}$ ), CAP with different carbonate contents could be obtained. The ratio of calcite/calcium hydroxide mixture played a crucial role for both the advancement of reaction and the carbonate content inserted in CAP's structure. At $80^{\circ} \mathrm{C}$, the total decomposition of calcite required a calcite/calcium hydroxide mixture containing at least a half of calcite. CAPs containing 2.25-4.17 wt\% of carbonate inserted in its structure were obtained as a function of the composition of calcite/calcium hydroxide mixture. The results open a simple but effective way for the synthesis of high quality biomimetic CAP.
\end{abstract}

Keywords:

A. Structural materials

B. Chemical synthesis

C. Thermogravimetric analysis

D. Microstructure

D. Thermal expansion

\section{Introduction}

Calcium hydroxyapatite $\left(\mathrm{Ca}_{10}\left(\mathrm{PO}_{4}\right)_{6}(\mathrm{OH})_{2}, \mathrm{Ca}-\mathrm{HA}\right)$ is found to be the main mineral phase of human hard tissues [1]. However, pure Ca-HA never occurs in any biological system but co-exists with its derivatives [2]. These are formed by partial replacement of calcium $\left(\mathrm{Ca}^{2+}\right)$, orthophosphate $\left(\mathrm{PO}_{4}{ }^{3-}\right)$ or hydroxide $\left(\mathrm{OH}^{-}\right)$groups by other species such as $\mathrm{Mg}^{2+}, \mathrm{Na}^{+}, \mathrm{K}^{+}, \mathrm{F}^{-}, \mathrm{Cl}^{-}$, and $\mathrm{CO}_{3}{ }^{2-}[3,4]$. Among them, carbonated apatite (CAP) is the closest biomimetic solid resembling the minerals in calcified tissues [4-6]. The amount of carbonate present in human bone mineral reaches typically $4-8 \mathrm{wt} \%[3,7]$. Recent studies showed that substituted Ca$\mathrm{HA}$, such as CAP, were more effective than pure Ca-HA for skeletal implants [7-9]. This leads to a growing interest in the development of such substituted materials.

Many hydroxyapatite types have been synthesized, characterized and examined for use as implantable bone-compatible biomaterials [10-12]. In synthesis procedures for pure Ca-HA, atmospheric carbon dioxide can be incorporated in the precipitated solids which lead to phosphate substitution with carbonate ions. This yields Ca-HA with low carbonate content and

\footnotetext{
* Corresponding author. Tel.: +33 563493258; fax: +33 563493043.

E-mail addresses: doan.phamminh@mines-albi.fr, doanhoa2000@yahoo.fr (D. Pham Minh).
}

non-stoichiometric $\mathrm{Ca} / \mathrm{P}$ ratios $[13,14]$. Only the more closely stoichiometric Ca-HA withstands the high temperature related to ceramic sintering or plasma-spraying, without decomposition into lime or tricalcium phosphate (TCP). CAP containing higher carbonate amounts can be synthesized by multi-step synthesis procedures including the precipitation of soluble calcium salts $\left(\mathrm{Ca}^{2+}\right)$ with $\mathrm{PO}_{4}{ }^{3-}$ in the presence of $\mathrm{CO}_{3}{ }^{2-}$ (liquid route) [15] or the heating up to more than $1000{ }^{\circ} \mathrm{C}$ of a calcium phosphate under carbon dioxide flux (thermal route) [16]. These methods have disadvantages of added manipulations for the elimination of waste counter ions or heating step under controlled carbon dioxide. CAP starting from calcium carbonate as the source of both calcium cations $\left(\mathrm{Ca}^{2+}\right)$ and carbonate anions $\left(\mathrm{CO}_{3}^{2-}\right)$ and potassium dihydrogen orthophosphate $\left(\mathrm{KH}_{2} \mathrm{PO}_{4}\right)$ under atmospheric pressure was briefly mentioned by Lomo [17]. This route has recently been investigated under higher pressures of hydrothermal conditions $[15,18,19]$. Despite the severe reaction conditions used (high temperature, long reaction time and water rinsing), the conversion of calcium carbonate was not complete [19]. So, it is of current interest to find simple synthesis procedures that lead to CAP with controlled carbonate contents.

In this study, the synthesis of CAP using calcium carbonate (calcite), calcium hydroxide and orthophosphoric acid was investigated under moderate conditions. Orthophosphoric acid was chosen because of its strongest acidity among the available orthophosphate sources and the absence of alkali cations in the final CAP product. 
Table 1

Composition of the starting reactant mixtures and designation of solid products; other condition: synthesis temperature of $80^{\circ} \mathrm{C}$; stirring rate of $800 \mathrm{rpm}$; initial water of $45 \mathrm{~g}$.

\begin{tabular}{lcll}
\hline Calcium source & & $\begin{array}{l}\text { Phosphate } \\
\text { source }\end{array}$ & $\begin{array}{l}\text { Solid product } \\
\text { designation }\end{array}$ \\
\hline $\mathrm{CaCO}_{3}$ & $\begin{array}{l}\mathrm{Ca}(\mathrm{OH})_{2} \\
\text { powder, mmol }\end{array}$ & $\begin{array}{l}\mathrm{H}_{3} \mathrm{PO}_{4}, \\
\mathrm{mmol}^{2}\end{array}$ & \\
\hline powder, mmol & 0 & 66.7 & CAP100/0 \\
\hline 100 & 25 & 66.7 & CAP75/25 \\
75 & 50 & 66.7 & CAP50/50 \\
50 & 75 & 66.7 & CAP25/75 \\
25 & & & \\
\hline
\end{tabular}

Various molar ratios of calcium carbonate to calcium hydroxide were used in order to control the amount of carbonate inserted in the apatitic structure. The results showed that CAP with different carbonate contents could be obtained in a one-step synthesis at $80{ }^{\circ} \mathrm{C}$ and pressures below $13 \mathrm{~atm}$, without a washing step.

\section{Materials and methods}

Calcite powder $\left(\mathrm{CaCO}_{3}, 98 \mathrm{wt} \%\right)$ from Fisher Scientific, calcium hydroxide powder $\left(\mathrm{Ca}(\mathrm{OH})_{2}, 98 \mathrm{wt} \%\right)$ from Acros Organics and orthophosphoric acid $\left(\mathrm{H}_{3} \mathrm{PO}_{4}, 85 \mathrm{wt} \%\right.$ in water) from Merck were used as received. CAP synthesis was carried out in a $250 \mathrm{~mL}$ stainless steel reactor (Top Industrial) which was equipped with an electrical heating jacket and a magnetic stirrer. For each reaction, calcite or mixture of calcite/calcium hydroxide containing $100 \mathrm{mmol}$ of calcium and $45 \mathrm{~mL}$ of water were fed into the reactor. After closing, $66.7 \mathrm{mmol}$ of orthophosphoric acid were quickly injected into the reactor. This led to the starting molar ratio of calcium to phosphorus of 1.67 (Table 1 ). During the reaction, the stirring rate was set at $800 \mathrm{rpm}$ and the reactor was thermostated at $80^{\circ} \mathrm{C}$ for $48 \mathrm{~h}$. This reaction temperature was chosen because supplementary experiments showed that the temperatures lower than $80^{\circ} \mathrm{C}$ were not sufficient for a good decomposition of calcite particles. After $48 \mathrm{~h}$ of reaction, the reactor was freely cooled down to room temperature. Solid products were separated from liquid phase by filtration using $0.45 \mu \mathrm{m}$ filter paper. Then they were dried at $50{ }^{\circ} \mathrm{C}$ for $48 \mathrm{~h}$ before further characterizations.

Both solid and liquid phases obtained from the filtration step were analyzed using different analysis and characterization techniques. Elemental analysis was carried out using inductively coupled plasma atomic emission spectroscopy (ICP-AES, HORIBA Jobin Yvon Ultima 2 apparatus). Thermogravimetry (TG) was performed in a TA Instruments SDTQ600 analyzer with a heating rate of $5^{\circ} \mathrm{C} \mathrm{min}-1$ under air flux (100 $\left.\mathrm{mL} \mathrm{min}^{-1}\right)$. Thermo-mechanical analysis (TMA) was carried out in a SETARAM SetSys 16/18 analyzer with $5 \mathrm{~g}$ constant load on the powder sample. X-ray diffraction (XRD) data of the solids collected using a Phillips Panalytical X'pert Pro MPD diffractometer with a $\mathrm{Cu}$ $\mathrm{K} \alpha(1.543 \AA)$ radiation source. Fourier transform infrared (FTIR) spectroscopy was performed using a Shimadzu 8400 S spectrometer. Particle size distribution was determined by laser scattering in a Mastersizer 2000 (Malvern Instruments Ltd., Malvern, UK) in the particle size range of $0.020-2000 \mu \mathrm{m}$. Scanning electron microscopy (SEM) was carried out on a Philips XL30 ESEM apparatus (FEI Company) which was coupled with an energy-dispersive X-ray spectroscopy (EDX analysis).

\section{Results}

\subsection{Elemental analysis}

The liquid separated from the filtration of the reaction mixture was acidified with concentrated nitric acid to avoid all further
Table 2

Results of elemental analysis using ICP-AES technique; $\mathrm{Ca}^{\text {Liq }}$ and $P^{\text {Liq }}$ : amount of calcium and phosphorus remained in the liquid phase; $\mathrm{Ca} / \mathrm{P}$ : molar ratio of bulk solid products.

\begin{tabular}{llll}
\hline Solid & $\mathrm{Ca}^{\text {Liq }}(\%)$ & $P^{L i q}(\%)$ & $\mathrm{Ca} / \mathrm{P}$ \\
\hline CAP100/0 & 1.4 & 1.1 & 1.88 \\
CAP75/25 & 0.9 & 1.2 & 1.84 \\
CAP50/50 & 1.4 & 1.2 & 1.82 \\
CAP25/75 & 1.3 & 1.2 & 1.74 \\
\hline
\end{tabular}

re-precipitation. Solid products were mineralized using concentrated nitric acid. The resulting homogeneous solutions were analyzed by ICP-AES technique and results are presented in Table 2. In all cases, the contents of soluble calcium and phosphorus in the liquid phase were lower than $1.4 \%$ of the initial quantities of calcium and phosphorus introduced in the reactor. So, the precipitation of orthophosphate species was quite complete and most of the calcium existed in solid phases after $48 \mathrm{~h}$ of reaction. Because of the absence of any counter ions in the liquid phase, no washing step was required for the purification of the final solid products. This brings a significant advantage of the present synthesis process in comparison with the synthesis using soluble calcium salts and/or alkali orthophosphates, since the washing step is usually arduous when small particles are formed.

The molar ratios of the bulk solids were higher than that of the stoichiometric Ca-HA (1.67). This result is discussed in more details in the section of FTIR analysis.

\subsection{Decomposition of calcium carbonate}

The reaction of calcite with orthophosphoric acid led to the formation of carbon dioxide which can exist in both gas and soluble states. Pressure in the reactor increased with the formation of carbon dioxide in gas phase. Taking into account the volume of gas phase in the reactor, the partial pressure of water vapor at $80^{\circ} \mathrm{C}$ and using the ideal gas law, the quantity of carbon dioxide in gas phase could be calculated from the final pressure at $48 \mathrm{~h}$ of reaction. Fig. 1 indicates the relative advancement of the reaction via the calculated amounts of carbon dioxide. The decomposition of calcite reached at least $43,89,83$ and $88 \%$ in the syntheses using $25,50,75$ and $100 \%$ of calcite as calcium source, respectively,

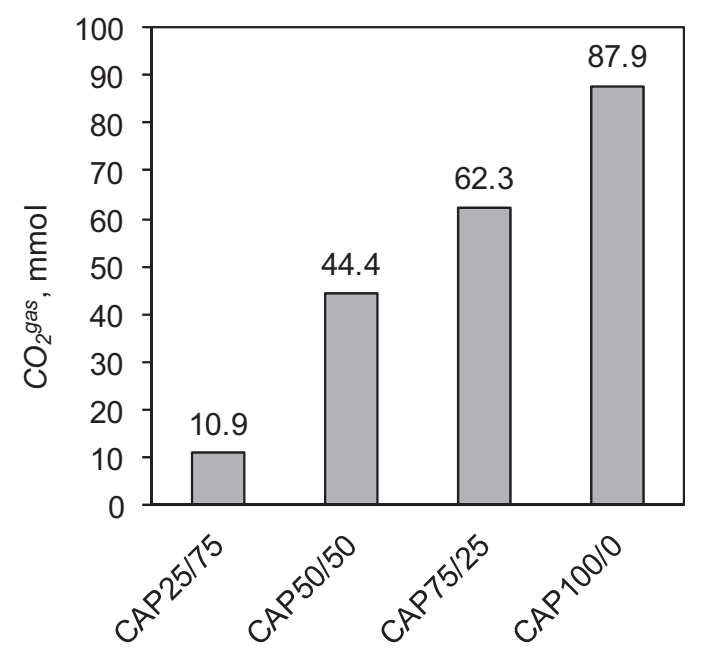

Fig. 1. Quantity of carbon dioxide in gas phase $\left(\mathrm{CO}_{2}^{\text {gas }}\right)$ calculated from the final reaction pressure as a function of the molar percentage of calcite in the initial mixture of calcite and calcium hydroxide. 


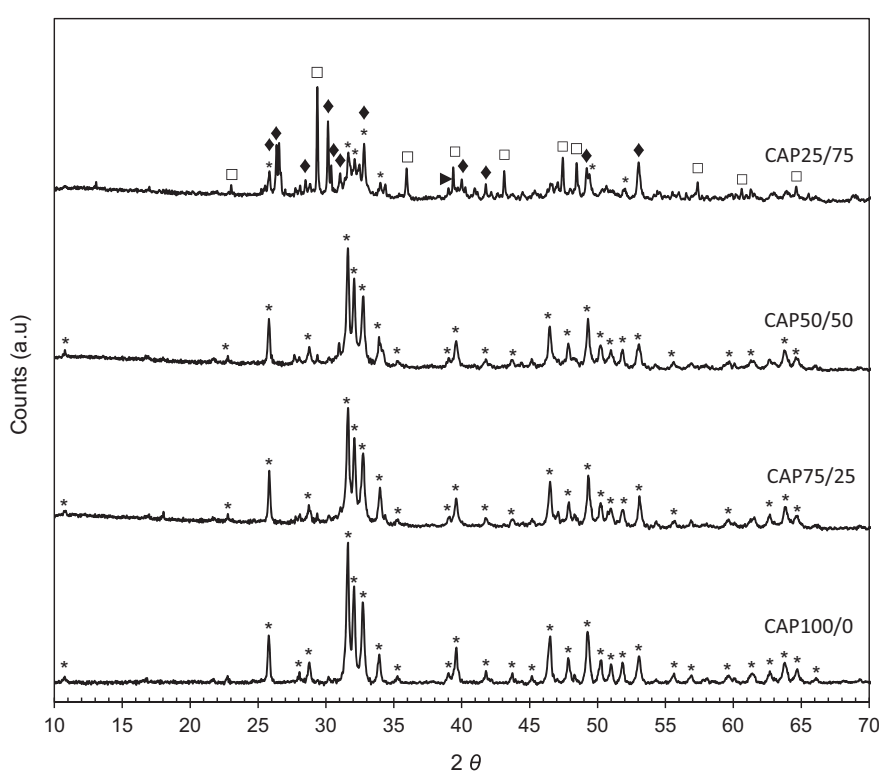

Fig. 2. XRD patterns of the solid products; $\left({ }^{*}\right)$ Ca-HA (JCPDS standard No 01-0721243); ( $\square$ ) calcite (JCPDS standard No 00-047-1743); ( ) OCP (JCPDS standard N0 00-026-1056); ( ) calcium hydroxide (JCPDS standard No 00-050-0008).

which does not consider the amount of carbon dioxide dissolved in the liquid phase.

\subsection{XRD characterization}

In order to identify crystalline phases of the solid products, XRD characterization was performed and the results are presented in Fig. 2. For the solid product starting from $100 \%$ calcium carbonate (CAP100/0), all diffraction peaks could be attributed to calcium hydroxyapatite (Ca-HA). CAP might be also present but they seemed to be relatively low in comparison with that of Ca-HA. No evidence of calcium carbonate was observed, indicating that the decomposition of the initial calcite must be quite complete for this synthesis.

Both CAP75/25 and CAP50/50 products, which were formed from the mixture of calcite and calcium hydroxide, had similar XRD patterns compared to that of CAP100/0. Most of their peaks could be also attributed to $\mathrm{Ca}-\mathrm{HA}$. Trace amounts of octocalcium phosphate (OCP, $\left.\mathrm{Ca}_{8}\left(\mathrm{HPO}_{4}\right)_{2}\left(\mathrm{PO}_{4}\right)_{4} \cdot 5 \mathrm{H}_{2} \mathrm{O}\right)$ could be also found. In fact, the final $\mathrm{pH}$ of the reaction mixture was around $7-8$. This $\mathrm{pH}$ is favorable for the formation of OCP because in this $\mathrm{pH}$ range, the main soluble phosphate species are $\mathrm{H}_{2} \mathrm{PO}_{4}{ }^{-}$and $\mathrm{HPO}_{4}{ }^{2-}$ [26]. This result was supported by previous work on the synthesis of $\mathrm{Ca}$-HA under similar conditions, at atmospheric pressure [26]. As observed previously for CAP100/0, calcite was almost absent in these two solid products, which was in agreement with the results in Fig. 1.

On the other hand, the results changed notably for CAP25/75. Calcite, Ca-HA and OCP were found to be the main crystalline phases present in this sample. A small amount of crystalline calcium hydroxide was found, as illustrated by the low intensity of its main diffraction peak at $39.06^{\circ}$. Calcium hydroxide has higher solubility and basicity than calcite. Thus, orthophosphoric acid introduced in the mixture of calcite and calcium hydroxide preferentially consumes the calcium hydroxide. When a high amount of calcium hydroxide is used such as for the synthesis of CAP25/75, the $\mathrm{pH}$ of reaction mixture remains at high value, which disfavors the decomposition of calcite.

In all cases, XRD results revealed the presence of CAP at levels much lower than those of Ca-HA. The identification of CAP by XRD is delicate because in most cases, the main diffraction peaks of CAP are close to those of Ca-HA and would require Rietveld refinement for increased resolution. Other characterization techniques were used to highlight the formation of CAP.

\subsection{IR characterization}

IR spectra of the solid products are presented in Fig. 3. In the wavenumber range from 4000 to $1700 \mathrm{~cm}^{-1}$ (not presented), there

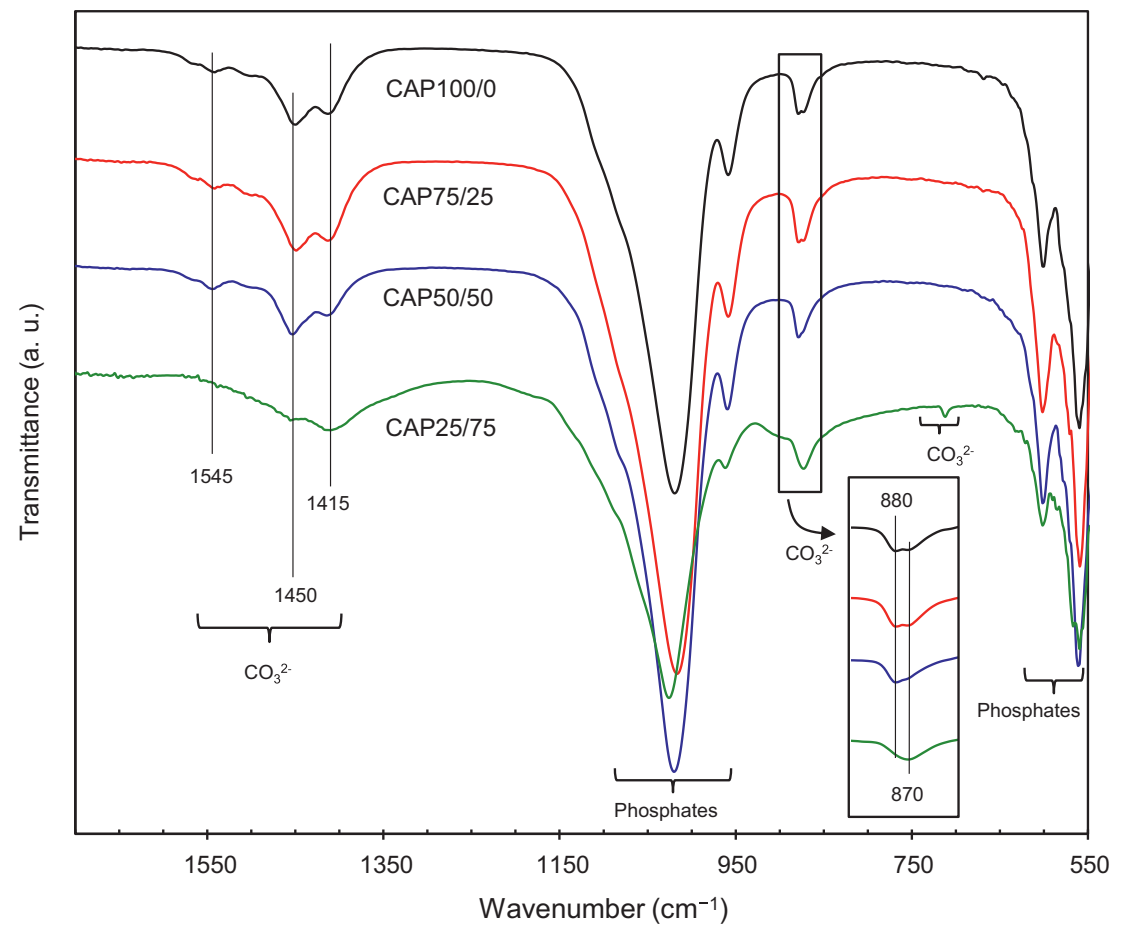

Fig. 3. IR spectra of the solid products. 

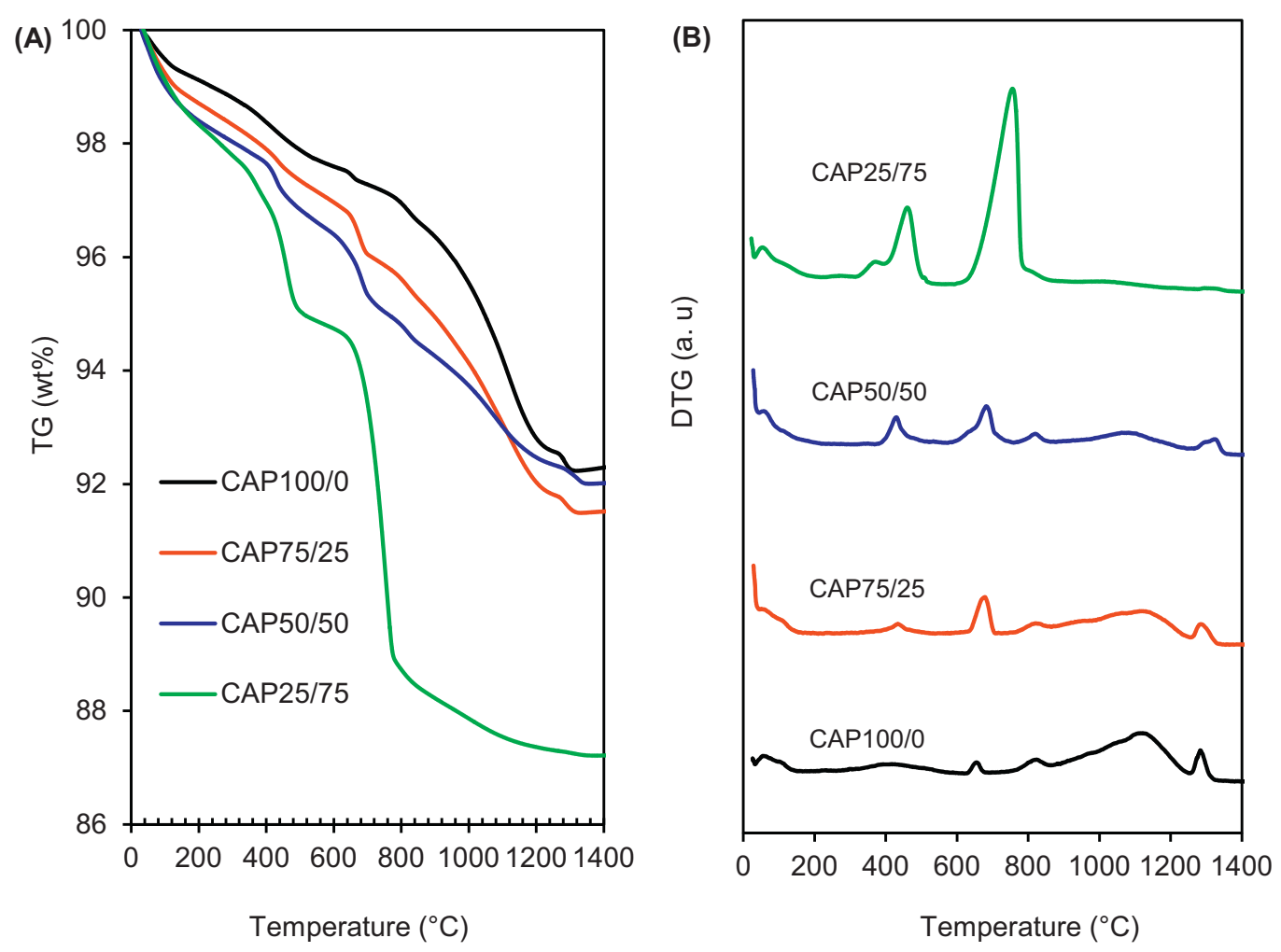

Fig. 4. TG (A) and DTG (B) curves of the solid products analyzed in the temperature range of $25-1400{ }^{\circ} \mathrm{C}$ under air atmosphere.

was only a very broad weak peak around $3500 \mathrm{~cm}^{-1}$, which is attributed to the stretching of molecular water. The vibrations of orthophosphate groups are characterized by the absorption bands in the wavelength ranges of $650-550 \mathrm{~cm}^{-1}$ and $1300-910 \mathrm{~cm}^{-1}$ [20]. According to XRD results, calcite was only notably present in CAP25/75 as confirmed by its net absorption band at $711 \mathrm{~cm}^{-1}$. This is one principal band of calcite and is not superimposed with bands of orthophosphates groups or carbonates groups present in apatitic structure [21].

The presence of carbonate groups inserted in the apatitic structure to form CAP was clearly revealed by IR spectra. The replacement of $\mathrm{PO}_{4}{ }^{3-}$ groups present in Ca-HA's structure by $\mathrm{CO}_{3}{ }^{2-}$ groups led to the formation of B-type CAP, which is characterized by the bi-modal peak at $1450 / 1415 \mathrm{~cm}^{-1}$ and the peak at $870 \mathrm{~cm}^{-1}[22,23]$. Thus, B-type CAP was present in all solid products but its content was higher in CAP100/0, CAP75/25 and CAP50/50 than that in CAP25/75. The higher intensity at $1415 \mathrm{~cm}^{-1}$ compared to that at $1450 \mathrm{~cm}^{-1}$ of CAP25/75 was due to the principal peak at $1389 \mathrm{~cm}^{-1}$ of calcite that remained in this product. The formation of B-type CAP explained the molar ratio of $\mathrm{Ca} / \mathrm{P}$ in Table 1 , which was slightly higher than that of the stoichiometric Ca-HA. On the other hand, A-type CAP is formed when $\mathrm{OH}^{-}$groups of Ca-HA's structure are replaced by $\mathrm{CO}_{3}{ }^{2-}$ groups, which have the characteristic bands at 1545 and $880 \mathrm{~cm}^{-1}$ $[22,23]$. So, A-type CAP was only formed in CAP100/0, CAP75/25 and CAP50/50, and was practically not present in CAP25/75.

\subsection{Thermal analysis (TG)}

Fig. 4 shows the results of the thermal analysis of the products in the wide range of temperatures from 25 to $1400{ }^{\circ} \mathrm{C}$. A weight loss smaller than $1 \mathrm{wt} \%$ took place below $100{ }^{\circ} \mathrm{C}$ which corresponds to the removal of surface moisture. The next weight loss of $1-2 \mathrm{wt} \%$, which occurred continuously from $100{ }^{\circ} \mathrm{C}$ to about $340-380^{\circ} \mathrm{C}$, could be attributed to the removal of lattice molecular water
$[24,25]$. The weight loss in the temperature range of $380-500{ }^{\circ} \mathrm{C}$ was attributed to the condensation of $\mathrm{HPO}_{4}{ }^{2-}$ groups, present in nonstoichiometric apatite such as OCP, to form calcium pyrophosphate $\left(\mathrm{Ca}_{2} \mathrm{P}_{2} \mathrm{O}_{7}\right)$, which was observed for all products. Remaining calcite decomposed at $610-670{ }^{\circ} \mathrm{C}$ [26]. DTG signal of both the condensation of $\mathrm{HPO}_{4}{ }^{2-}$ groups and the decomposition of calcite increased with the increase of calcium hydroxide content in the initial reactant mixture. This showed the unfavorable effect of calcium hydroxide content for the decomposition of calcite, as explained in XRD section. According to XRD results, unreacted calcium hydroxide remained only notably in CAP25/75. Its thermal decomposition is characterized by two separated peaks [27]. The first weight loss starting at $325^{\circ} \mathrm{C}$ was partially superimposed with the condensation of $\mathrm{HPO}_{4}{ }^{2-}$ groups, and the second weight loss starting at $600{ }^{\circ} \mathrm{C}$ was practically superimposed with the thermal decomposition of calcite, highlighted by its DTG curve.

The decarbonation of CAP took place in the temperature range of $670-1250{ }^{\circ} \mathrm{C}$. According to IR results, A-type CAP was practically not present in CAP25/75. Thus, we deduce that the thermal decarbonation of A-type CAP and B-type CAP took place at 870$1250{ }^{\circ} \mathrm{C}$ and $670-870^{\circ} \mathrm{C}$, respectively. Finally, the last weight loss at $1250-1340{ }^{\circ} \mathrm{C}$ was attributed to the dehydration of $\mathrm{OH}^{-}$groups present in Ca-HA's structure [28].

Table 3

Carbonate contents in the solid products determined by TG analysis.

\begin{tabular}{lclll}
\hline Product & $\mathrm{CO}_{3}{ }^{2-}(\mathrm{wt} \%)$ & & \\
\cline { 2 - 5 } & $\mathrm{CaCO}_{3}$ & $\begin{array}{l}\text { B-type CAP } \\
(610-670\end{array}$ & & A-type CAP \\
$\left(670-780^{\circ} \mathrm{C}\right)$ & $\left(780-1250{ }^{\circ} \mathrm{C}\right)$ & $\left.\begin{array}{l}\mathrm{CAP} \\
(670-1250\end{array}{ }^{\circ} \mathrm{C}\right)$ \\
\hline $\mathrm{CAP} 100 / 0$ & 0.30 & 0.63 & 3.5 & 4.17 \\
$\mathrm{CAP75} / 25$ & 0.75 & 0.69 & 2.73 & 3.42 \\
$\mathrm{CAP50} / 50$ & 1.20 & 0.63 & 1.62 & 2.25 \\
$\mathrm{CAP} 25 / 75$ & $<4.7^{\mathrm{a}}$ & 0.54 & 0 & 0.54
\end{tabular}

a Superimposition of TG signals of $\mathrm{CaCO}_{3}$ decomposition and $\mathrm{Ca}(\mathrm{OH})_{2}$ dehydration, giving an approximate value. 

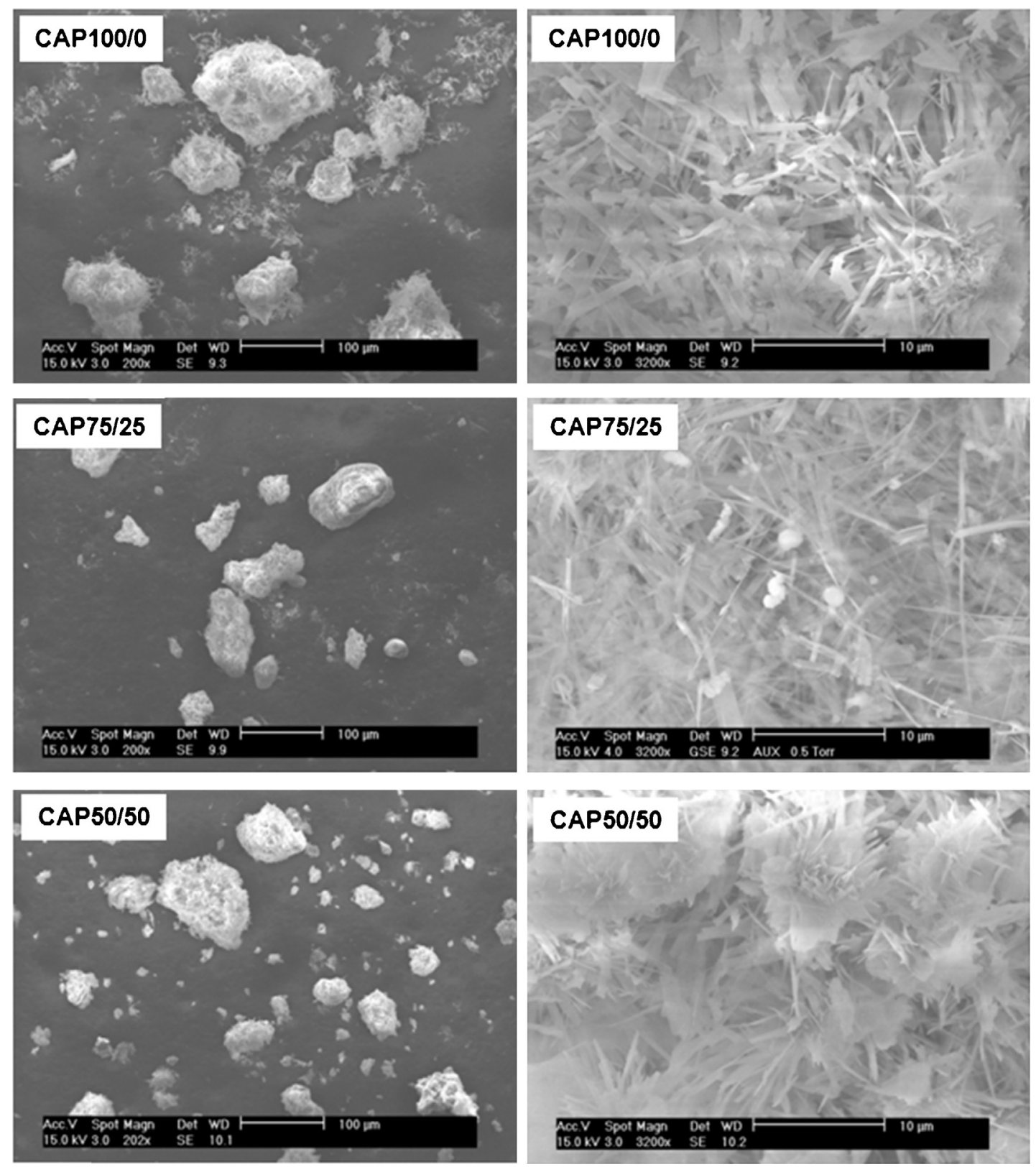

Fig. 5. SEM images of CAP100/0, CAP75/25 and CAP50/50.

From TG curves in Fig. 4, the content of different types of carbonate present in the solid products could be calculated (Table 3). As observed by XRD characterization, the increase of calcium hydroxide content in the initial mixture of calcium source led to the increase of remaining calcite content. In all cases, the carbonate contents of B-type CAP were close to each other. On the other hand, the carbonate content of A-type CAP decreased with the increase of calcium hydroxide content in the initial mixture of calcium source, which was in good agreement with IR results. The total amount of carbonate obtained in CAP100/0 and CAP75/25 approximated the amount of carbonate present in the mineral phase of bone, dentin and enamel, which is in the range of $4-8 \%$ $[3,7,22]$. It is evident that the composition of the initial mixture of calcium source is an efficient parameter to control the carbonate content for the one-step synthesis of CAP, since the conversion of both initial calcium and orthophosphate sources into desired solid products was practically total in the synthesis of CAP100/0, CAP75/
25. CAP50/50. Taking into account the quasi-complete decomposition of calcite, the high selectivity in apatitic compounds and the weight of the solid products recovered after filtration and drying steps, the yield of the synthesis procedure in desired CAP powder could be calculated which reached at least $97 \%$ for CAP100/0, CAP75/25 and CAP50/50.

\subsection{SEM, particle size distribution}

The results of SEM observation are illustrated in Figs. 5 and 6. In the left-hand side of Fig. 5 ( $100 \mu \mathrm{m}$ scale), particles of sizes ranging from several $\mathrm{nm}$ to hundreds of $\mu \mathrm{m}$ could be observed for CAP100/ 0, CAP75/25 and CAP50/50. The images on the right-hand side of Fig. $5(10 \mu \mathrm{m}$ scale) revealed that the larger particles consisted of the agglomeration of smaller ones.

The agglomerates of these solids had a flat-needle-like morphology. This was previously observed for apatitic calcium phosphates 

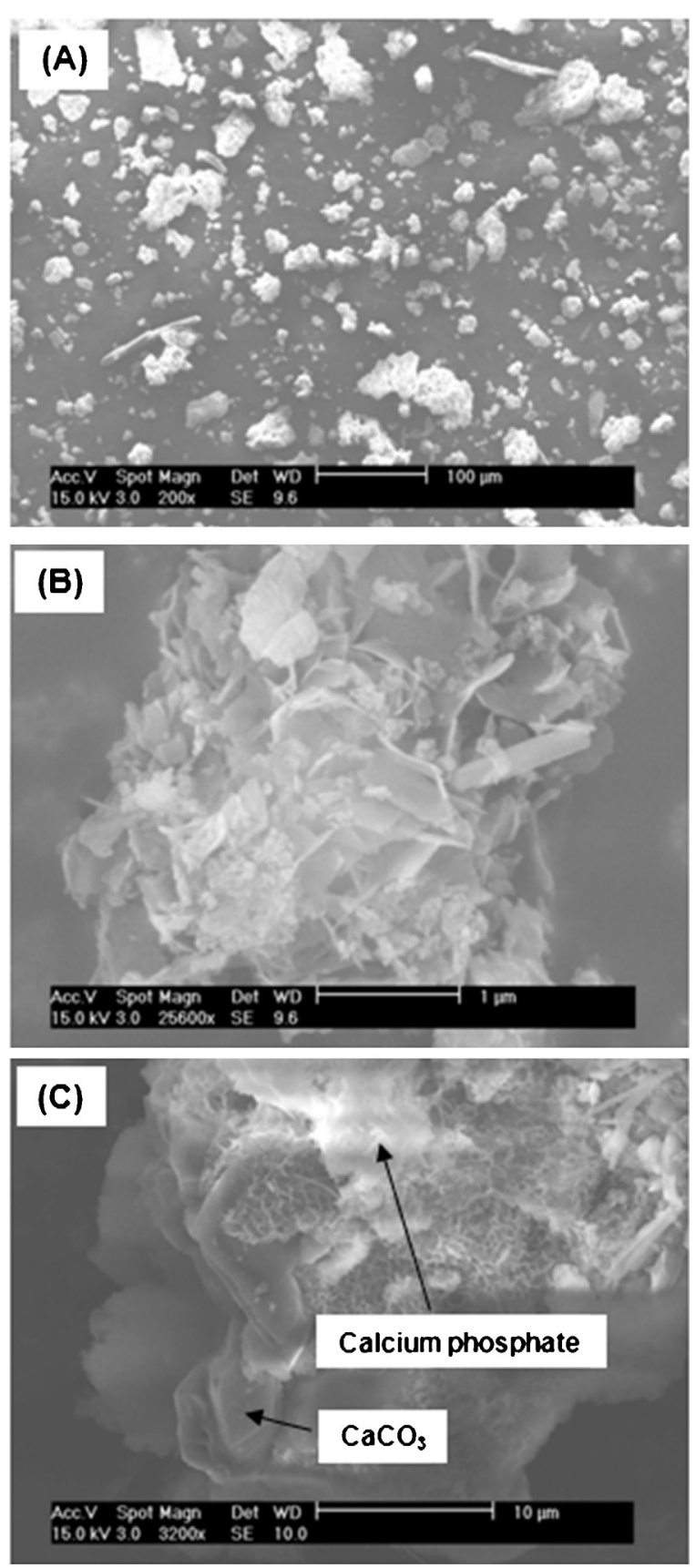

Fig. 6. SEM images of CAP25/75.

synthesized under hydrothermal conditions [19,29] or at atmospheric pressure [30]. The formation of these particles could be attributed to the growth of CAP particles along the $c$-axis direction, where $\mathrm{CO}_{3}{ }^{2-}$ groups replaced $\mathrm{OH}^{-}$groups $[31,32]$. For CAP50/50, in addition to the presence of particles of flat-needle-like morphology, particles of sheet structure could be also observed, which were attributed to apparent morphology of OCP, which contains $\mathrm{HPO}_{4}^{2-}$ groups [33].

SEM images of CAP25/75 are shown in Fig. 6. At $100 \mu \mathrm{m}$ scale corresponding to a magnification of 200 times (Fig. 6(A)), particle sizes varied also in a large range as observed in Fig. 5 for other solids. At higher magnification, calcium phosphate particles of sheet-like structure were clearly observed, which was attributed to the presence at large amount of OCP (Fig. 6(B)). Remaining calcite particles were also frequently present, as confirmed by EDX analysis (Fig. 6(C)). We observed also that the remaining calcite particles were usually covered by calcium phosphate layers. This explained why the FTIR signal of calcite was not significant despite its high content in CAP25/75 (Fig. 3).

To better quantify the results of SEM observations, particle size distribution was examined and Fig. 7 shows the volume distribution as a function of particle size. The initial calcite powder had a Gaussian distribution in the particle size ranging from 6 to $70 \mu \mathrm{m}$. On the other hand, the initial calcium hydroxide had different categories of particle sizes, which varied from $0.3 \mu \mathrm{m}$ to about $240 \mu \mathrm{m}$.

The volume distribution of all four solid products can be classified into two categories. The first one consisted of fine particles ranging from 0.35 to about $1.5 \mu \mathrm{m}$. The volume occupied by this category was not significant and did not exceed $1.4 \%$ of the total volume of the solids. The second one included particles larger than $1.5 \mu \mathrm{m}$, which stretched up to $310,400,450$ and $710 \mu \mathrm{m}$ for CAP100/0, CAP75/25, CAP50/50 and CAP25/75, respectively, indicating different levels of agglomeration of particles for each product. The higher the calcium hydroxide content was, the higher the $\mathrm{pH}$ of calcite/calcium hydroxide mixture was, and the more the acid-base reaction was violent leading to stronger agglomeration. In all cases, these results confirmed SEM observations of Figs. 5 and 6.

\subsection{Thermo-mechanical analysis}

Used as biometerials, apatitic calcium phosphate based products can be stabilized at high temperature in order to avoid all further evolution of materials. This section was dedicated to the study of the thermo-mechanical behavior of CAP100/0 as the selected product.

Thermal shrinkage is defined as $\left(L-L_{0}\right) / L_{0}$ or $\Delta L / L_{0}$, where $L_{0}$ is the initial length of sample, and $L$ is the length of sample measured at temperature $T$ or time $t$. Fig. 8(A) shows the non-isothermal analysis of the CAP100/0 sample in the temperature range of 30$1000^{\circ} \mathrm{C}$. The temperature of $880^{\circ} \mathrm{C}$ was found to be the critical point for the thermal shrinkage of CAP100/0 where the shrinkage accelerated. Only a slight thermal effect on the shrinkage was observed below $880{ }^{\circ} \mathrm{C}$ which was smaller than $0.02 \%$. On the other hand, it became significant above $880{ }^{\circ} \mathrm{C}$ and reached $-0.46 \%$ when the temperature rose to $1000^{\circ} \mathrm{C}$ (Fig. 8(A)).

Fig. 8(B) illustrates the isothermal shrinkage at different temperatures before and after the critical point. The initial value of $\Delta L / L_{0}$ of each curve corresponded to the shrinkage of the sample

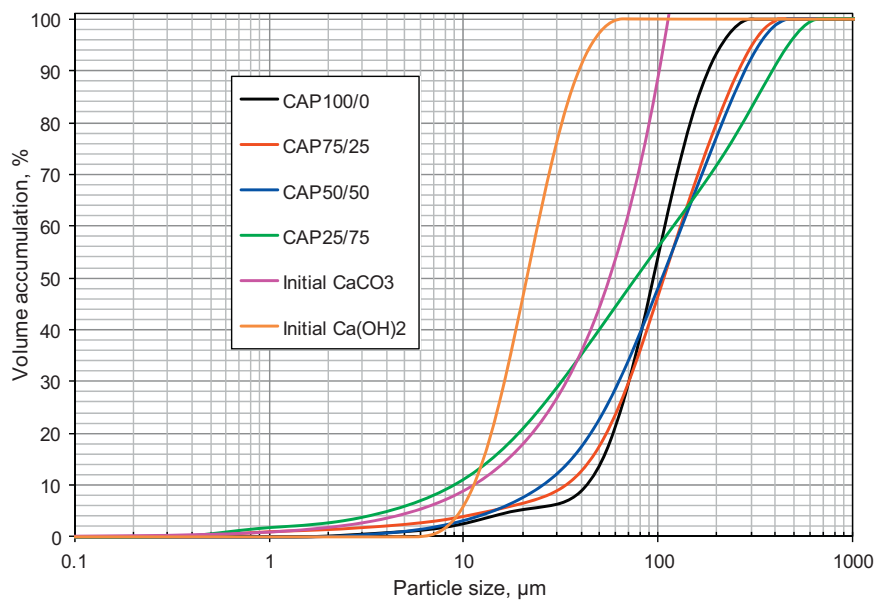

Fig. 7. Volume distribution as a function of particle size (in base 10 logarithmic scale). 

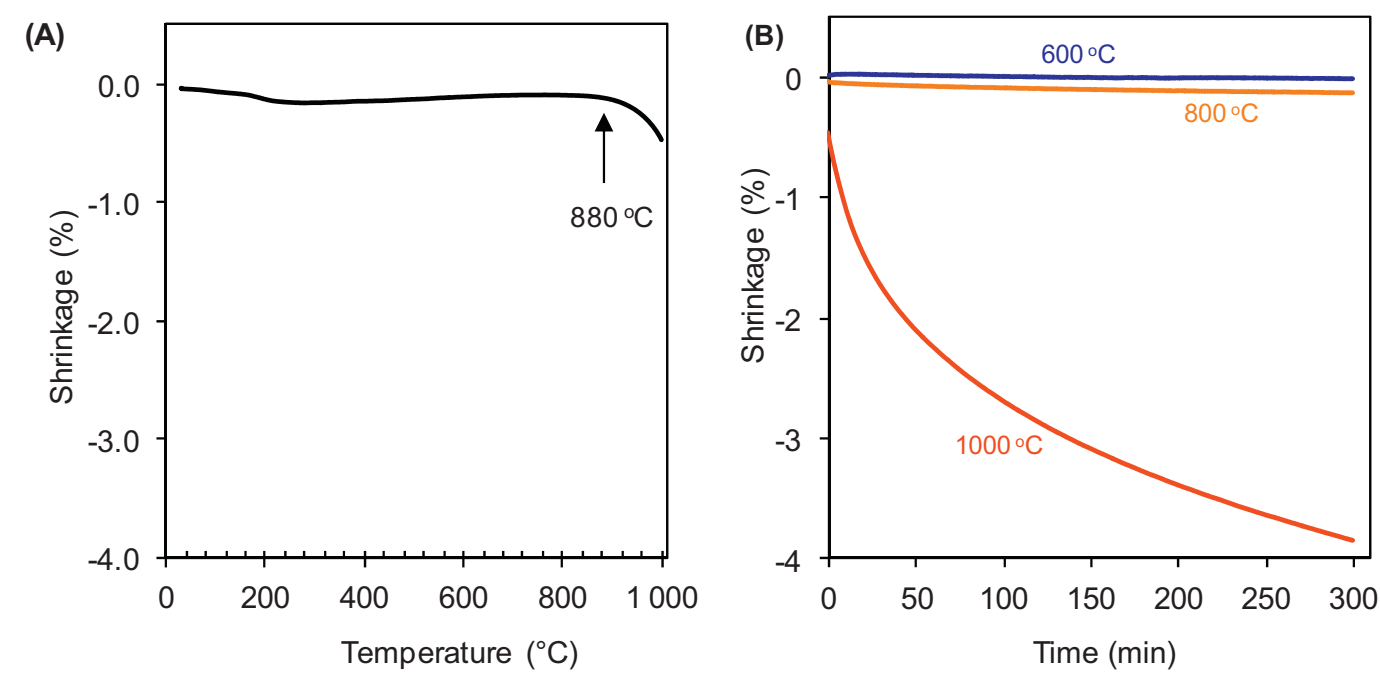

Fig. 8. TMA of CAP100/0; (A) non-isothermal analysis with the heating rate of $10{ }^{\circ} \mathrm{Cmin}^{-1}$; (B) isothermal analysis.

during the heating time to reach the desired temperature. No significant thermal effect was observed at 600 and $800^{\circ} \mathrm{C}$ for an isothermal time of $300 \mathrm{~min}$, confirming that CAP100/0 was thermo-mechanically stable at these temperatures. As expected, the isothermal shrinkage took place at $1000{ }^{\circ} \mathrm{C}$ and reached $-3.85 \%$ after $300 \mathrm{~min}$.

The thermal shrinkage can be attributed to the sintering phenomenon wherein denser mass is formed and chemical reaction, i.e. the decarbonation or dehydration. Fig. 9 shows SEM images of CAP100/0 sample after TMA. The isothermal time of
$300 \mathrm{~min}$ at 600 and $800^{\circ} \mathrm{C}$ had no significant effect on the surface morphology of CAP particles, compared to the solid before thermal treatment (Fig. 5 for the CAP100/0 sample). At $1000{ }^{\circ} \mathrm{C}$, particles of flat-needle-like morphology became only partially rounded. Probably, this morphology distortion of CAP particles corresponded to the first step of sintering wherein the formation of the contact areas between adjacent particles started [34].

TG analysis showed that the heating of CAP solids led to different chemical reactions. We are interested in the thermal stability of carbonate anions present in apatitic structure of CAP. As
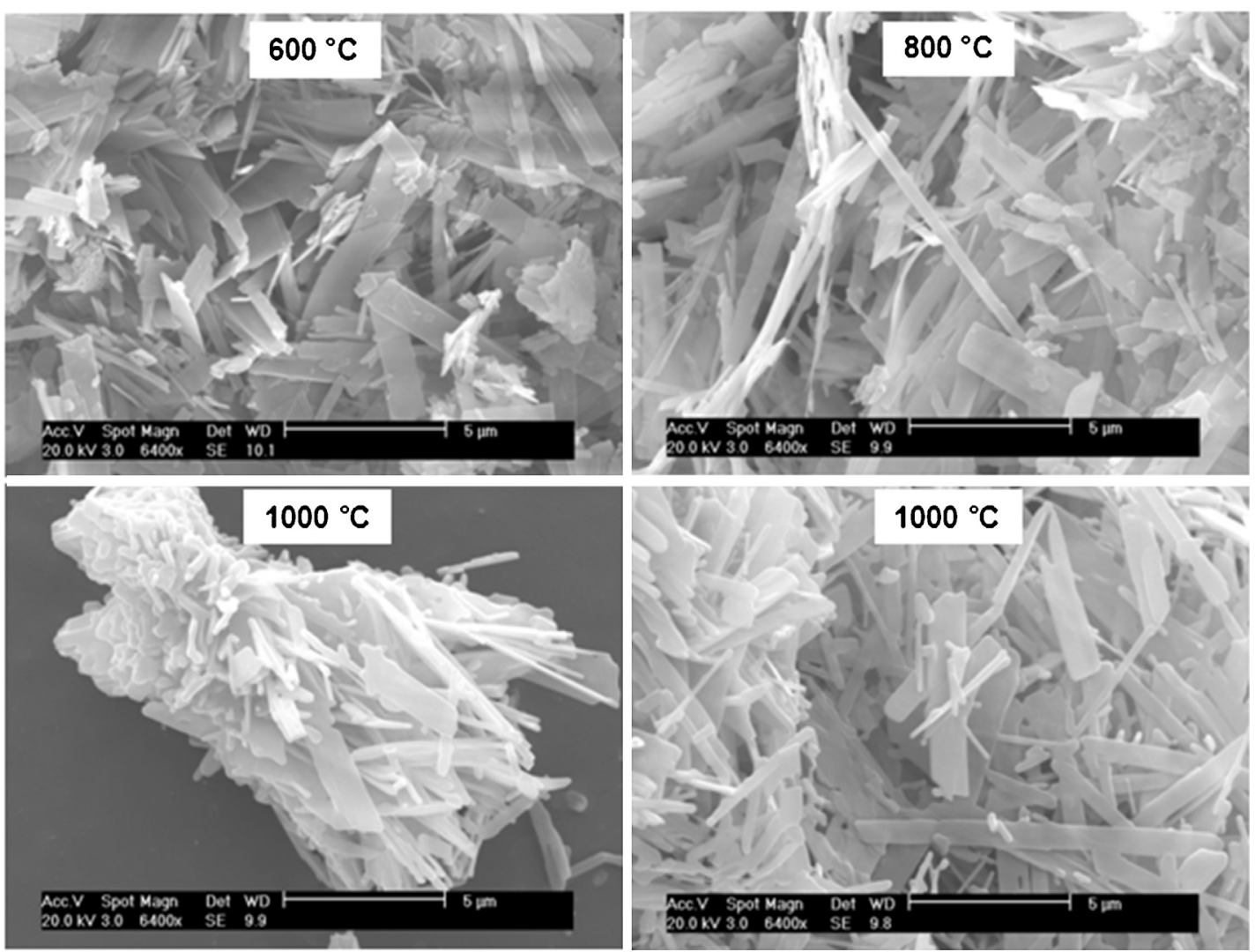

Fig. 9. SEM images of CAP100/0 after sintering at different temperatures. 


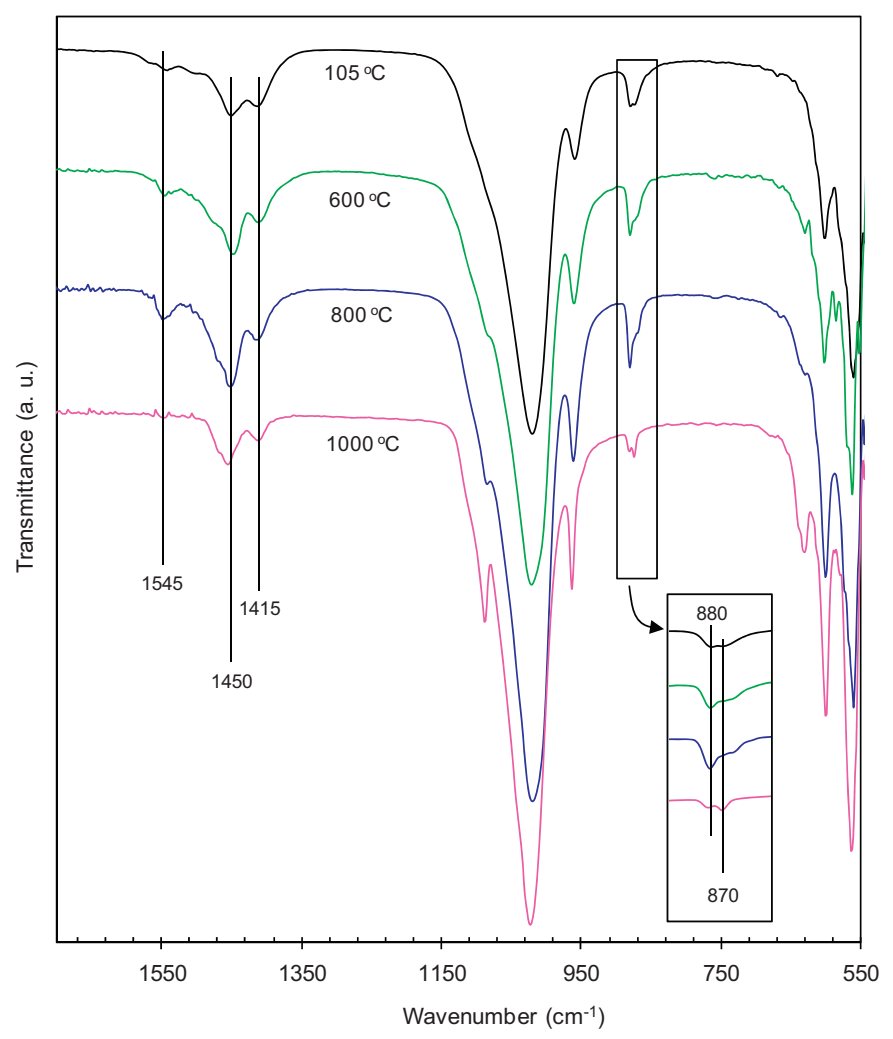

Fig. 10. IR spectra of CAP $100 / 0$ before $\left(105^{\circ} \mathrm{C}\right)$ and after $\left(600,800\right.$ and $\left.1000{ }^{\circ} \mathrm{C}\right)$ TMA.

shown in Fig. 10 for IR spectra of CAP100/0 sample before and after TMA, the decarbonation of both A-type (bands at 1545 and $880 \mathrm{~cm}^{-1}$ ) and B-type (bands at 1450, 1415 and $870 \mathrm{~cm}^{-1}$ ) CAP was only partial after the plateau time of $300 \mathrm{~min}$ at different temperatures. This demonstrates the possibility to stabilize CAP using thermal treatment while conserving its carbonate content.

\section{Conclusions}

For the first time, carbonated apatite (CAP) of high purity was successfully synthesized by a one-step synthesis process using orthophosphoric acid, and a mixture of calcite and calcium hydroxide as simple starting reactants under moderate conditions $\left(80^{\circ} \mathrm{C},<13 \mathrm{bar}\right)$. Carbon dioxide was formed as the only byproduct and no washing step was required for the purification of final products. Both A-type and B-type CAP were formed under the synthesis conditions used.

The total content of carbonate inserted in apatitic structure could be controlled by varying the calcite content in the initial mixture of calcium source. We obtained CAP containing 2.25$4.17 \mathrm{wt} \%$ of carbonate with the initial mixture of calcium source containing $50-100 \%$ calcite. For a complete decomposition of calcite, an initial mixture of calcite and calcium hydroxide containing at least $50 \%$ of calcite was mandatory.

The CAP100/0 sample prepared from $100 \%$ calcite and containing $4.17 \%$ carbonate, was found to be thermo-mechanically stable up to $880^{\circ} \mathrm{C}$. This offers a good possibility for the synthesis of CAP for biomedical applications.

\section{Acknowledgments}

The authors acknowledge gratefully colleagues at RAPSODEE center, Nathalie Lyczko, Christine Rolland and Philippe Accart for different characterization measurements.

\section{References}

[1] R.Z. LeGeros, Chem. Rev. 108 (2008) 4742-4753.

[2] S.V. Dorozhkin, M. Epple, Angew. Chem. Int. Ed. 41 (2002) 3130-3146.

[3] N. Nassif, F. Martineau, O. Syzgantseva, F. Gobeaux, M. Willinger, T. Coradin, S. Cassaignon, S. Padilla, I. Izquierdo-Barba, M. Vallet-Regí, Chem. Mater. 22 (2010) 3653-3663.

[4] S. Padilla, I. Izquierdo-Barba, M. Vallet-Regí, Chem. Mater. 20 (2008) 5942-5944.

[5] H. Morgan, R.M. Wilson, J.C. Elliott, S.E.P. Dowker, P. Anderson, Biomaterials 21 (2000) 617-627.

[6] K. Onuma, Prog. Cryst. Growth Charact. Mater. 52 (2006) 223-245.

[7] Y.S. Kim, H.K. Kwon, B.I. Kim, J. Dentistry 39 (2011) 636-642.

[8] A.E. Porter, N. Patel, J.N. Skepper, S.M. Best, W. Bonfield, Biomaterials 24 (2003) 4609-4620.

[9] E.S. Thian, Z. Ahmad, J. Huang, M.J. Edirisinghe, S.N. Jayasinghe, D.C. Ireland, R.A. Brooks, N. Rushton, W. Bonfield, S.M. Best, Biomaterials 29 (2008) 1833-1843.

[10] S. Peroos, Z. Du, N. Henriette de Leeuw, Biomaterials 27 (2006) 2150-2161.

[11] Q. Bao, C. Chen, D. Wang, J. Liu, Cryst. Growth Design 8 (2008) 219-223.

[12] L. Niu, H. Kua, D.H.C. Chua, Langmuir 26 (2010) 4069-4073.

[13] S.R. Radin, P. Duchyne, J. Biomed. Mater. Res. 27 (1993) 35-45.

[14] A. Afshar, M. Ghorbani, N. Ehsani, M.R. Saeri, C.C. Sorrell, Mater. Design 24 (2003) 197-202.

[15] O. Frank-Kamenetskaya, A. Kol'tsov, M. Kuz'mina, M. Zorina, L. Poritskaya, J. Mol. Struct. 992 (2011) 9-18.

[16] T. Tonegawa, T. Ikoma, Y. Suetsugu, N. Igawa, Y. Matsushita, T. Yoshioka, N. Hanagata, J. Tanaka, Mater. Sci. Eng. B 173 (2010) 171-175.

[17] L.A. Lomo, J. Am. Chem. Soc. 76 (1954) 3924-3925.

[18] T.I. Ivanova, O.V. Frank-Kamenetskaya, A.B. Kol'tsov, V.L. Ugolkov, J. Solid State Chem. 160 (2001) 340-349.

[19] A. Kasioptas, T. Geisler, C. Perdikouri, C. Trepmann, N. Gussone, A. Putnis, Geochim. Cosmochim. Acta 75 (2011) 3486-3500.

[20] D.W. Kim, I.S. Cho, J.Y. Kim, H.L. Jang, G.S. Han, H.S. Ryu, H. Shin, H.S. Jung, H. Kim, K.S. Hong, Langmuir 26 (2010) 384-388.

[21] D. Pham Minh, M. Galera Martinez, A. Nzihou, P. Sharrock, J. Therm. Anal. Calorim. 112 (2013) 1145-1155

[22] A. Antonakos, E. Liarokapis, T. Leventouri, Biomaterials 28 (2007) 3043-3054.

[23] M.E. Fleet, Biomaterials 30 (2009) 1473-1481.

[24] S. Lazic, S. Zec, N. Miljevic, S. Milonjic, Thermochim. Acta 374 (2001) 13-22.

[25] W.L. Suchanek, P. Shuk, K. Byrappa, R.E. Riman, K.S. TenHuisen, V.F. Janas, Biomaterials 23 (2002) 699-710.

[26] D. Pham Minh, N.D. Tran, A. Nzihou, P. Sharrock, Ind. Eng. Chem. Res. 52 (2013) $1439-1447$.

[27] M.J. Hologado, V. Rives, S. San Roman, J. Mater. Sci. Lett. 11 (1992) 1708-1710.

[28] C.J. Liao, F.H. Lin, K.S. Chen, J.S. Sun, Biomaterials 20 (1999) 1807-1813.

[29] K. Ioku, S. Yamauchi, H. Fujimori, S. Goto, M. Yoshimura, Solid State Ionics 151 (2002) $147-150$

[30] M. Aizawa, T. Terado, F.S. Howell, K. Itatani, Mater. Res. Bull. 34 (1999) $1215-1225$.

[31] J. Xiao, Y. Zhu, Q. Ruan, Y. Liu, Y. Zeng, F. Xu, L. Zhang, Cryst. Growth Des. 10 (2010) 1492-1499.

[32] M.E. Fleet, X. Liu, Biomaterials 28 (2007) 916-926.

[33] S. Mandel, A.C. Tas, Mater. Sci. Eng. C 30 (2010) 245-254.

[34] S. Bailliez, A. Nzihou, Chem. Eng. J. 98 (2004) 141-152. 